\title{
General Editors' Preface
}

A brief history of Lonergan's teaching and writing in the area of trinitarian theology is given at the beginning of the General Editors' Preface to the companion volume, The Triune God: Systematics. ${ }^{1}$ Prior to 1961 the texts that Lonergan wrote on the Trinity were concerned with the systematic understanding of trinitarian doctrine, and not, as the present text, with specifying precisely what that doctrine is and how it developed. The major systematic text on the Trinity prior to 1961 was Divinarum personarum conceptionem analogicam evolvit Bernardus Lonergan, S.I., published in 1957 and reissued in 1959 by Gregorian University Press. In 1961 Lonergan published with the same press De Deo Trino: Pars analytica, which in revised form became in 1964 De Deo Trino: Pars dogmatica, published together with De Deo Trino: Pars systematica, a revised version of Divinarum personarum. As the Pars systematica was the basis for the Collected Works edition published as The Triune God: Systematics, so the Pars dogmatica is the basis for the present work. As The Triune God: Systematics included in its appendix 4 the paragraphs and pages of Divinarum personarum that were changed in De Deo Trino: Pars systematica, so the present work indicates in appendices 1-4 portions of the 1961 text that were revised for the work published in 1964 .

This is a very different work from its systematic counterpart. Perhaps the simplest way of indicating the difference is in terms of the contrast between

1 Robert M. Doran, 'General Editors' Preface,' The Triune God: Systematics, vol. 12 in Collected Works of Bernard Lonergan, trans. Michael G. Shields, ed. Robert M. Doran and H. Daniel Monsour (Toronto: University of Toronto Press, 2007) xvii-xviii. 
the analytic way or way of discovery and the synthetic way or way of teaching and learning. The present work traces the way of discovery up to and including the formulation of the trinitarian doctrines and concludes with an introductory statement of the psychological analogy that will provide the starting point of the way of teaching and learning employed in The Triune God: Systematics. The two works are classic exemplars of what Lonergan means by these two ways of doing theology.

The distinction of the two ways, of course, became greatly differentiated when Lonergan reached the notion of functional specialization in 1965 . He had not yet had that major breakthrough when the final trinitarian texts were published. We can see him inching toward it in the introduction to the present work, with its distinction of dogmatic, systematic, and positive theology, as well as (less clearly in some ways) in the first chapter of The Triune God: Systematics. But in each case, one gets the sense, 'So near, and yet so far.' A major intellectual Ereignis occurred in February 1965, when Lonergan differentiated theology into eight functional or operational specialties. We are publishing the Collected Works version of the present text some forty-plus years later, and the astounding breakthrough that occurred in 1965 has entered so much into the mentality of those who have studied Lonergan that the impact that it originally made can hardly be appreciated by those who grew up in a post-Method in Theology culture. In some ways the present work in particular (more than the systematic volume, which very much embodies what the later Lonergan would have considered the functional specialty 'systematics') will probably be viewed by future historians of theology and theological method as a work that simply would not have been written after the breakthrough of 1965 . For it cannot be said (despite the title that Frederick Crowe and I chose for this work a number of years ago) that this book is an exercise purely and simply in the functional specialty 'Doctrines,' as The Triune God: Systematics surely is an exercise in the functional specialty 'Systematics.' In terms of the categories supplied by functional specialization, the present work contains elements from various other functional specialties besides Doctrines: in particular, Interpretation, History, and Dialectic. In some ways the text is representative of the situation that prevailed in the years when Lonergan taught at the Gregorian University, a situation that he was later to call 'impossible.' He called the conditions impossible because no one person could be expected to do everything that the setup was calling for, since no one can be an expert in eight functional specialties. But if the present work says anything about its author, it tells us that if anyone came close to doing everything that the setup was demanding, that person was 
Bernard Lonergan, at least in composing this book. The amount of historical research that went into the composition of the work is astounding for someone whose principal specialization as a professor was in the strictly systematic portion of theology.

Even if it is true, however, that other functional specialties besides Doctrines function in a central fashion in the present work, the thrust of the work definitely is doctrinal, the direct-discourse statement of what is so, rather than the indirect discourse of exegesis and history. This point is made in other words in its introduction, and it is clear from the execution in the two major parts that Lonergan never let go of this doctrinal objective for the book as a whole, an objective that is represented especially in the formulation of the five theses that make up part 2 of the book. Part 1 is an exercise in what later would be called the functional specialty Dialectic, and can only be appreciated if it is understood as such. Its concern with historical judgments is in the interest of sorting out the positions and counterpositions on the 'way to Nicea' and reducing them to their roots in implicit assumptions regarding cognitional theory. That is pure Dialectic.

Mention of the way to Nicea prompts me to mention one of the more difficult decisions made by the editors. When we began the work, we fully intended that the translation of the Latin 'Praemittenda' that was done by Conn O'Donovan and published in 1976 under the title The Way to Nicea ${ }^{2}$ would be incorporated into the present work. Thus part 2 was translated before part 1 , since it was only when we recognized that, for reasons of consistency with the style and the choice of translation for certain key words in part 2, we would have to do our own rendition of the 'Praemittenda' as well that we changed our plans. This kind of decision is particularly hard to make, and the difficulty was accentuated by our recognition of the tremendous service that O'Donovan's translation performed over the past thirty years and more.

I proceed now to the details of editing. Michael Shields has indicated to me that he can't imagine anyone else who would have taken greater pains in researching the very large number of footnotes than Daniel Monsour, and so I begin by thanking Danny and by indicating one of the decisions that he made. Lonergan indicates in a footnote at the very end of the Latin text (below p. 738) that he 'occasionally made a clearer or more accurate [Latin]

2 Bernard Lonergan, The Way to Nicea: The Dialectical Development of Trinitarian Theology, trans. Conn O'Donovan (London: Darton, Longman \& Todd, and Philadelphia: Westminster, 1976). 
translation of the Greek passages quoted in [the series graeca of the Migne Patrologiae cursus completus].' We have indicated several notable instances of such changes, but for the most part have just allowed them to stand as Lonergan made them. However, Daniel Monsour made a decision to change some of the references to columns in Migne. While this may not be important to most readers, it would awaken some curiosity on the part of anyone who is comparing our text to the original, and so I state in his own words the four rules that Monsour followed: 'Where Lonergan quoted Latin text from the Greek Fathers and cited the Latin column in MG (his most frequent practice), I did not change the reference to the Greek column; where he quoted Latin text from the Fathers and cited the Greek column, I changed the reference to the Latin column; where he did not quote but merely referred to a text from the Greek Fathers and cited the Latin column, I changed it to the Greek column; and where he did not quote but merely referred to a text from the Greek Fathers and cited the Greek column, I did not change the reference. It seemed to me when I was working on the notes that Lonergan was not always completely consistent in the way he cited MG, but I tried to make his citations consistent with the four rules just mentioned.' Some of the apparent inconsistencies may be explained by the practice of changing some of the Latin translations of Greek text, but it seemed to us that a consistent policy should be followed, and that Monsour's seemed eminently reasonable.

In most of the volumes of the Collected Works the editors have transliterated Greek characters, but in the present volume we have followed the policy of leaving the Greek characters where Lonergan's own text gave them. At times in the Latin text he transliterated the Greek but in other instances he did not. We follow his usage precisely.

Translations from scripture are often Michael Shields's work, as are most of the translations from patristic writings.

As with the systematics volume, so here the Latin text placed some paragraphs in smaller print. We have followed that practice on the Latin side, while the English facing pages maintain the same print size throughout.

The abbreviations of a number of reference works given toward the end of this volume appeared in Lonergan's own text, except for a few that the editors have added in brackets.

We have added a bibliography of modern authors both for the sake of readers and in order to avoid repeating bibliographical information for some works that are frequently cited. That information is provided only in the first footnote in which a work is mentioned. 
A special word of thanks must be expressed to Marquette University for the support the University has provided to the Collected Works project. Approximately half of my working time has been put into editing the Collected Works since I moved to Marquette in August 2006. Without the University's generosity in providing me with an office, a budget, and a salary, my work on the Collected Works would probably have been forced to come to an end a couple of years ago. All costs from my end for the project, including mailing costs for parcels to my editorial colleagues in Toronto, have been generously absorbed by the University, which has now established a special fund for the Lonergan work.

I conclude by thanking Michael Shields for yet another superlative translation of an important work in the series and by indicating once again how indebted we are to Daniel Monsour for his painstaking devotion to the minutiae of editing. I am very fortunate to be working with such fine collaborators on this important project.

ROBERT M. DORAN

Marquette University 
This page intentionally left blank 